\title{
Insecticide Potential of Botanic Extracts Obtained from the Flora of the Brazilian North East Region
}

\section{Thayanne Nicolly de Araújo Soares, Vitor Leony Ferreira de Oliveira, Geovani Gonçalves Dias,} Agronomic Engineering Graduation Student, Scientific Initiation Scholarship Holder, Department of Technology and Social Sciences, Bahia State University, Campus III.

\section{Meridiana Araújo Gonçalves Lima,}

Agronomic Engineer (UNEB), Agronomy Mastership, Doctor in Fitopathology (UFRPE), PNPD/CAPES Scholarship Holder in the Post

Graduation Program of Human Ecology and Socioenvironmental Administration (PPGEcoH).

Carlos Alberto Batista Santos, (Biologist (UPE), Master of Zoology (UESC), Doctor in Ethnobiology and Nature Conservation (UFRPE), Coordinator of the Post Graduation Program in Human Ecology and Socioenvironmental Management (PPGEcoH).

Doi: 10.19044/esj.2018.v14n18p1 URL:http://dx.doi.org/10.19044/esj.2018.v14n18p1

\begin{abstract}
This article provides a literature review pointing out the relevance of plant extracts as an economically possible and ecologically sustainable alternative to the use of chemical compounds in the management and control of the insects in agriculture. The methodology was constituted in a literature review, through researches in Scielo and Lilacs, from 1990 to 2018. Organic farming is gaining importance in the Brazilian economy. The consumers are more and more conscious and demanding, choosing healthy foods, free from chemical residuals, deemed as harmful to the health. Botanic extracts can control insects and pathogens, providing no contamination for the soil, for the drinkable water sources, and leaving no toxic residuals in the environment. Studies focused on production and testing of these natural products deserve to be highlighted in the scientific literature. Only through the spreading of these studies, small producers and family farmers will access these informations.
\end{abstract}

Keywords: Plant extracts; Sitophilus zeamais; Sitotroga cerealella; Zea mays 


\section{Introduction}

Currently there is a market concern with food quality and the protection of the environment. However, in the opposite direction of this requirement, agriculture uses chemical products to increase the productivity of plants and to protect them against the attack of pests and diseases, compromising their organoleptic qualities (Souza \& Rezende, 2003), as a consequence the chemical products waste in the environment. An alternative to agrochemicals are plant extracts that act on insects in different ways, affecting their feeding, development and reproduction (Thomazini et al., 2000).

"Pest" is the word used to define any form of vegetal, animal, or any pathogenic agent, which is or potentially could be harmful to vegetables or their products (IBAMA, 2008).

Santos (2007) defines agriculture of forestry pests, a population of organisms which can cause harm to the plant, their products or subproducts. These damages can affect the production of a plant by the direct consumption of its tissues or organs, fruits, and seeds, suction of the sap, competition for space and available nutrients. Besides this, also the cost of the control of these pests shall be considered: the lower incomes from the harvests, the lower value of their products because of the damages, together with the cost of the control measures. All these features cause a severe reduction of the income for the farmers.

According to Santos (2007), the agricultural pest is the population of organisms that can reduce the quantity or quality of foods, feeds, fibers, flowers, or woods during the stages of production, harvest, industrialization, storage, transport or use. In agriculture, the concept of insect-plague is directly linked to the economic effects caused by its feeding on plants. A single insect would never be able to cause such damage that can redress its elimination from the culture. Just as these pests reach a high density, they will cause a loss to the exploited plant.

The term "Pest" shall be defined numerically, as population density. A determined population of the insect can be highlighted by the damages they cause in the different parts of the plant. This means, the visibility of the damages on the plant does not mean, that the production has been or will be affected (Santos, 2007).

\section{Methodology}

In search of the bibliographic material that constitutes the results of this research were used two databases: Scielo, and Lilacs. For the databases, the descriptors "Plant extracts", "Sitophilus zeamais", "Sitotroga cerealella" and "Zea mays" were used. After this first search, the documents were filtered from the inclusion and exclusion criteria. 145 papers published in national and 
international journals, written in vernacular (Portuguese); dating from 1990 to 2018, containing the descriptors in the title, abstract and / or body of the text. Monographs, Dissertations and Theses were excluded due to their dense volume, as well as articles published in annals.

After the filters were used, 44 articles were selected from the two databases, twenty-two from each database. This reduction was based on Goméz \& Machado (2007), who name gray material, the unpublished manuscripts, the manuscripts of authors that published outside the scientificacademic milieu and even material considered unscientific.

After a thorough and thorough reading of the 44 documents selected, three articles were eliminated because they were not relevant to the research objectives, and one to be presented was repeated on both platforms, and forty scientific articles were analyzed.

\section{Insects Affecting Maize Culture (Zea mays, L.)}

Maize culture is relevant at a worldwide level. It is one of leading food sources, used since its discovery in the Americas, and widespread worldwide. Brazil is the third major producer of this plant in the world (Silva \& Carvalho, 2000).

Many species of insects are associated with the production of maize, but just a few of them can be classified as "key-plague", with regular occurrence, geographic distribution, and potential to cause economically significant damages (Roscoe et al., 2013). The insects that attack the maize can cause losses since the beginning of the development of the plant. They reduce seeding density, and cause other damages along the production chain, up to indirect damages during the storage of the grains, and their derived products. Bibliography describes almost a hundred of species of phytophagous insects a pest of the maize (Gassen, 1996).

Storage is a main stage of the production to obtain high-quality seeds. Seeds need to be stored appropriately, otherwise the efforts, and the use of specific cultural techniques to provide their development may be lost (Grisi \& Santos, 2007).

Different elements may affect the quality of the stored maize. Among these, pest-insects. The wheat weevils, weevils and beetles Sitophilus zeamais (Motschulsky, 1855), Sitophilus oryzae (Linnaeus, 1763), Rhyzopertha dominica (Fabricius, 1792), Oryzaephilus surinamensis (Linnaeus, 1758), Tribolium castaneum (Herbst, 1797) and the angoumois grain moth Sitotroga cerealella (Olivier, 1789) may affect the quality of the stored maize (Pimentel; Santos; Lourini, 2001). Among these species, Sitophilus zeamais and Sitotroga ceralella are responsive for most of the loss (Santos, 2006). 


\section{Sitophilus zeamais (Motschulsky, 1855)}

S. zeamais, also known as weevil is a primary plague and is ubiquitous. The size of the seadults is 2.0 to $3.5 \mathrm{~mm}$. They are dark brown colored with white stains on the elytron, well visible after the emergence. The head is projected to the front as a curved rostrum. They display sexual dimorphism: the rostrum of the males is short and broad; that of females is longer and thinner (Lorini \& Schneider, 1994; Loeck, 2002),

This species of weevil can feed on several cultures, such as wheat, rice, corn, barley and triticale (Lorini, 2008). It is one of the most critical pests of the stored maize, as it may cause cross-infestation, id est this species can infest the grains both in the field and in the storage places. Besides these features, it also has excellent multiplication potential (Faroni, 1992). Its damages cause the reduction of both the weight and quality of the grains (Lorini \& Schneider, 1994).

The morphology of Sitophilus zeamays and Sitophilus oryzae is very similar: they differ only in the study of the genitalia. Both can coexist in the same mass of grains, independently of the type (Lorini, 2008).

\section{Sitotroga cerealella (Olivier, 1789)}

Also known as "angoumois grain moth", this species belongs to the order Lepidoptera, Family Gelechiidae (Athié; Paula, 2002). The adults are butterflies, having ten to $15 \mathrm{~mm}$ wingspan and six to eight $\mathrm{mm}$ length. Anterior wings are straw colored and fringed. Posterior wings are lighter colored, with larger fringes. Wings are silky and brilliant, being the anterior ones thin, long and sharp at their extremities. This species can be polymorphic, displaying different colors, sizes, and patterns. The eggs have an average length of 0.5 $\mathrm{mm}$, oval shape striped and white colored. Their color becomes pink, as the hatching approximates. Caterpillars are short and truncated, display little developed false abdominal legs with the maximum number of three crochets. At the beginning of the development, they are yellowish. As they develop, they become white, reaching six mm length. The shape of the caterpillar is curved; the thorax is wider than the abdomen, the mandibles are dark brown colored. The color of the pupa, having an average size of $6.5 \mathrm{~mm}$, varies during its development, being white at the beginning, or dark brown as the emergence is close (Fernandes, 2015).

According to Elias and Oliveira (2008), this species is a primary pest, feeding on the entire grains. Larvae destroy the grain alter its weight and quality. According to Barrer (1981), S. cerealella can infest developing grain or grains ripened in the field. They can survive several generations changing from one host to the other. Even the same, most of the infestations in the field begin probably close to the storage place. 


\section{Rhyzopertha dominica (Fabricius, 1792)}

Known as the "lesser grain borer", it is a coleopter of the Family Bostrychidae. It causes severe damages to the grains, leaving them perforated and with a significant amount of frass associated to its feeding habits. In a oneweek time, it can destroy five or six times its weight of grains (Poy, 1991). For its damaging capacity, it is considered the smaller existing cereal driller. The adult is two to three mm wide (Loeck, 2002).

In our country, it is the primary pest of wheat. This species is as one of the most damaging pests of stored wheat in the world, because of its high incidence and difficulty to avoid the losses it causes to the grains (Lorini, 2008).

Both adults and larvae can damage stored grains, feeding on the entire grain. They can feed on several species of grains: wheat, barley, triticale, paddy rice, oats, and corn. This pest can survive and develop in its frass (Koehler, 1994). The infestation occurs at storage, being rare in the field (Gallo et al., 2002).

\section{Tribolium castaneum (Herbst, 1797)}

This species is a coleopter of the Family Tenebrionidae. The adults are reddish brown colored, 2.3 to $4.4 \mathrm{~mm}$ length. The body is flattened and has two transversal depressions on the cephalic region. The biological cycle can vary from one to four months. Females lay 400 to 500 eggs (Gallo et al., 2002) in cracks in the walls, sacks, and on the grains. Larvae are yellowish white, cylindric, up to seven mm length. Adults can live up to four years in favorable conditions (Booth, Cox \& Madge, 1990).

T. castaneum is a quite well known secondary pest. It develops on the ground or into broken grains (Lorini et al., 2010; Antunes et al., 2011). Their frass is contaminating, allowing the development of microorganisms, such as fungi, which affect the quality of the flour and subsequently cause the fall of their economic value (Gigliolli, Lucena \& Lapenta, 2011).

\section{Oryzaephilus surinamensis (Linnaeus, 1758)}

This coleopter belongs to the Family Silvanidae. Adults are elongated beetles, flattened, dark-red colored. Their size varies between 1.7 and 3,3 $\mathrm{mm}$. They have three longitudinal keels in the pronotum, and six lateral tooth-like projections, which allow their identification (Booth, Cox \& Madge, 1990). Life cycle lasts from 24 to 50 days. Females lay their eggs in cracks of the grains or inside their mass, laying from 50 up to 300 eggs.

The biological features described above shall vary according to the conditions of the grains mass and according to temperature and humidity of the grains (Lorini, 2008). 
The adults and the larvae of $O$. surinamensis infest cereals, flours, dry fruits, chocolate, pasta, up to smoked meat (Nakano et al., 2002). It is considered secondary pest as it affects grains that have already been attacked by other species or that are imperfect (Howe, 1956).

\section{Botanical Extracts: Definition and Agronomic Ecologic Relevance}

Botanical extracts are concentrated preparations of various possible consistencies obtained from dry vegetal raw materials, that might have passed or not through a previous treatment, and prepared through a process using a solvent. The fabrication is a two-steps process, beginning with the separation of the specific compounds from a complex medium. The complex medium shall be a drug or a part of the used plant: root, stem or leaf (Revista Fi, 2010).

The extracts may have insecticide, fungicide, herbicide and nematicide potential, and are considered having good efficiency. Extracts can be obtained by cold extraction or warm extraction, in a closed or opened system. Vegetal extracts shall be an interesting and promising option for the integrated plant's protection. These products shall be an alternative for the control of phytopathogens, displaying excellent results and without causing any harm to the environment, or the living beings (Santos et al., 2013).

The use of vegetal extracts in plants protection has several advantages: the production of new chemical compounds, which cannot be inactivated by the pathogens, the lower toxicity in comparison with their synthetic correspondents, the rapid biodegradation, the wide action range and the derivation from renewable resources (Ferraz, 2008).

Vegetable extracts are a primary alternative for the pest control in small cultivation (vegetable gardens) and small grains storages (granaries, silos). In these conditions, their use is viable and sustainable (Dequech et al., 2008). The joint use of natural plants extracts and other techniques of pests control shall reduce the dosage and applications of synthetic chemical products (Machado, Silva \& Oliveira, 2007). The growth of organic productions in Brazil fostered the increase of the use of the organic products as an alternative to agrotoxic products, aiming to reduce the damages caused by these chemical compounds (Oliveira, 2013).

Several types of research have been developed dealing with the use of botanic extracts in the pest management.

Almeida, Goldfarb, and Gouveia (1999) studied the action of different extracts from the flora of the state of Paraiba (North Eastern Region of Brazil) to control the adult stage of Sitophilus spp. The authors pointed out, the extract applied as steam could kill 96 to $100 \%$ of the adults of this species.

Pontes (2005) analyzed the insecticide efficiency of vegetal extracts and oils on nymphs of cowpea aphid (Aphis craccivora Koch). The author tested alcoholic extracts of Cuban oregano (Plectranthus amboinicus, Lour.), 
basil (Ocimum basilicum L.), celery (Apium graveolens L.) and leek (Allium porrum L.). Their results confirmed the efficiency of $A$. graveolens and $A$. porrum.

Baldin et al. (2007) tested the insecticide activity of the essential oils extracted of typical plants of the North-Eastern region of Brazil against the Silverleaf whitefly (Bemisia argentifolii Bellows \& Perring), in the Muskmelon Cucumis melo (L.).

Souza and Evangelista (2009) analyzed the effects of plant extracts in the control of plagues in the familiar agriculture. The authors focused on the maize culture and the control of the fall armyworm Spodoptera. frugiperda Smith, 1797 (Lepidoptera: Noctuidae).

Migliorini, Lutinski, and Garcia (2010) laboratory tested the efficiency of vegetal extracts in the control of the "cucurbit beetle" Diabrotica speciosa (Germar, 1824), one of the main pests of beans and maize. The researchers studied nine vegetal species: sage (Salvia officinalis Linnaeus), cloves (Eugenia caryophyllata, Thunb), nutmeg (Myristica fragans Houtt), ash tree (Melia azedarach Linnaeus), "timbó" (Ateleia glazioveana Baill), eucalypt (Eucalyptus citriodora Hook), cinnamon tree (Cinnamomum zeylanicum Blume), Indian laurel fig (Ficus microcarpa Linnaeus f.) and the rosemary (Rosmarinus officinalis Linnaeus). The authors pointed out the extracts of "timbó", nutmeg, and ash tree as the most efficient. Their efficiency varied between 80.4 and $100 \%$.

Santos et al. (2011) tested the insecticide activity of the extracts of spices against the cowpea aphid (Aphis craccivora Koch) on "caupi" beans (Vigna unguiculata (L.) Walp.). All the extracts tested caused over $70 \%$ lethality and can be used as a natural insecticide.

Oliveira (2013) tested the potential use of vegetal extracts on the control of the broad mite (Polyphagotarsonemus latus), red spider mite (Tetranychus urticae), and the green peach aphid (Myzus persica). These species are polyphagous, cosmopolitan and can cause severe damages to agriculture production. The authors point out the vegetal extracts shall be an alternative for the control of these pests, besides allowing the survival and the better performance of their natural enemies.

Silva (2013) tested the use of extracts obtained from plants of the "caatinga" biome to control the opuntia cochineal scale (Dactylopius opuntiae L. (Mill.)) in the prickly pear cactus Opuntia ficus-indica Cockerell. The author observed over $50 \%$ lethality in the colonies of cochineals, after the treatment with the aqueous extracts of the plants. The results of this paper confirm the viability of the use of caatinga-native plants to treat the infestation by the opuntia cochineal scale in the prickly pear cactus. The use of vegetal species is an easy access practice and with low cost of production. 
Lima, Moreira, and Aragão (2013) assessed the action of vegetal extracts on the control of the Silverleaf whitefly Bemisia tabaci biotype $\mathrm{b}$ in the cucumber (Cucurbita moschata Duch.). The authors analyzed substances extracted from the bush morning-glory (Ipomoea carnea subsp. Fistulosa), the castor-oil plant (Ricinus communis L.), the "tinguí" (Mascagnia rígida Griesb), and the Mexican poppy (Argemone mexicana L.). All the extracts were effective on the control of the nymphs of $B$. tabaci.

Santos and Silva (2015a) studied the efficiency of exotic plants from the "caatinga" biome on the control of the cowpea aphid Aphis craccivora Koch on the cowpea (Vigna unguiculata (L.) Walp). The author studied the mesquite (Prosopis juliflora Sw. DC), the tropical almond (Terminallia catappa L.), the silver dollar tree (Eucalyptus cinerea F. Muell. ex Benth.), the large-leaved cordia (Cordia abyssinica R. Br.), the grey box (Eucalyptus moluccana Roxb.), the lead tree (Leucaena leucocephala Lam.), the Ben-oil tree (Moringa oleifera Lam.), the nim tree (Azadirachta indica A. Juss), the Brazilian orchid tree (Bauhinia forticata Benth) and the sisal (Agave sisalana Perrine ex Engelm) demonstrating, the highest mortality rates of the cowpea aphids are caused by the use of the extracts of the nim tree and the grey box.

The same authors tested extracts of weeds of the "caatinga" biome on the control of the cowpea aphid Aphis craccivora Koch on the cowpea (Vigna unguiculata (L.) Walp). These plants displayed an elevated insecticide effect, over $60 \%$ of the mortality rate of the aphids. This article demonstrates weeds shall be used to obtain natural insecticides or to obtain active principles from which new phytosanitary products shall be obtained (Santos \& Silva, 2015b).

Goergen (2016) analyzed the effects of the extracts from the Brazilian pepper (Schinus terebinthifolius Raddi) on the control of Sitophilus spp., the primary pest of the stored wheat grains. The authors demonstrated the control on the emergence and adults of Sitophilus spp. obtained by the use of the extracts of the Brazilian pepper plant.

\section{Conclusion}

The excessive use of agrochemicals for the management of pests that attack agriculture, or their use in a wrong manner, has caused several environmental impacts: contamination of the soil, water sources, wild and domestic animals, and men. These effects have caused severe biological unbalance and affected biodiversity.

In several cases, the development of resistance mechanisms by the insects reduced the efficiency of these chemical compounds. These mechanisms became more and more aggressive as generations succeeded.

As considering these limitations of agrochemical compounds, researchers worldwide have been studying less aggressive alternatives for pest management in agriculture. Botanical extracts have been used with success, 
providing considerable advantages in comparison with chemical products. The main advantage is that natural products derived from plants provided new active compounds, which insects and pathogens can not inactivate. Besides this, they are natural products, are less toxic, can be quickly degraded in the environment and derive from renewable sources.

The use of botanical extracts shall be an efficient alternative in integrated pest management. The studies that have been quoted in this article point out that natural products can have excellent results: they provide excellent efficiency in pest management and, at the same time, they harm neither the environment nor botanical and animal biodiversity in the areas surrounding agricultural ecosystems.

\section{Acknowledgments}

We would like to thank FAPESB (Foundation for the support to Research of the State of Bahia), CNPq, (National Council for Scientific and Technologic development) and UNEB (University of the State of Bahia) for the grants provided to the students of the program for scientific initiation (Programas de iniciação científica).

\section{References:}

1. Almeida, F. A. C., Goldfarb, A. C. \& Gouveia, J. P. G. (1999). Avaliação de extratos vegetais e métodos de aplicação no controle de Sitophilus spp. Revista brasileira de produtos agroindustriais. v.1, n.1, p.13-19.

2. Antunes, L. E. G., Viebrantz, P. C., Gottardi, R. \& Dionello, R. G. (2011). Características físico-químicas de grãos de milho atacados por Sitophilus zeamais durante o armazenamento. Revista Brasileira de Engenharia Agrícola Ambiental, v.15, n. 6, p. 615-620.

3. Athié, I. \& Paula, D. C. (2002). Insetos de Grãos Armazenados Aspectos Biológicos e Identificação. Varela, $2^{\circ}$ edição, p. 28-34.

4. Baldin, E. L. L. (2007). Controle de mosca branca com extratos vegetais, em tomateiro cultivado em casa de vegetação. Horticultura Brasileira 25: 602-606.

5. Barrer, $\mathrm{P}$.

(1981).

M. The biology of Lepidoptera associated with stored grain.

In: Proc. Aust. Dev. Asst. Course on Preservation of Stored Cereals, p.186196.

6. Booth, R. G., Cox, M. L. \& Madge, R. B. (ed.) (1990). III Guides to insects of importance to man: 3. Coleoptera. International Institute of Entomology/ The Natural History Museum. London: The University Press, $384 \mathrm{p}$. 
7. Dequech, S. T. B., Sausen, C. D., Lima, C.G. \& Egewarth, R. (2008). Efeito de extratos de plantas com atividade inseticida no controle de Microtheca ochroloma Stal (Col.: Chrysomelidae), em laboratório. Biotemas, p.22-31.

8. Elias, M. C. \& Oliveira, M. (2008). Formação de Auditores Técnicos do Sistema Nacional de Certificação de Unidades Armazenadoras. Pelotas: Editora Santa Cruz, 461p.

9. Faroni, L. R. A. (1992). Manejo das pragas de grãos armazenados e sua influência na qualidade do produto final. Revista Brasileira de Armazenamento, v. 76, p. 36-43.

10. Fernandes, J. (2015). Sitophilus zeamais e Sitotroga cerealella: Pragas do Milho. Disponível em: http://www.agronegocios.eu/noticias/sitophilus-zeamais-e-sitotrogacerealella-pragas-do-milho/.

11. Ferraz, S. (2008). Controle de fitonematoides com o uso de extratos e óleos essenciais de plantas. In: Poltronieri, L. S. \& Ishida, A. K. N. (ed). Métodos alternativos de controle de insetos-praga, doenças e plantas daninhas. Panorama atual e perspectivas na agricultura. Belém: EMBRAPA Amazônia Oriental, 308. p.

12. Gallo, D., Nakano, O., Silveira Neto, S., Carvalho, R. P. L., Batista, G. C., Berti Filho, E., Parra, J. R. P., Zucchi, R. A., Alves, S. B. \& Vendramim, J. D. (2002). Manual de entomologia agrícola. 2. ed. São Paulo: Agronômica Ceres, 649 p.

13. Gassen, D. N. (1996). Manejo de pragas associadas à cultura do milho. Passo Fundo: Aldeia Norte, 134p.

14. Gigliolli, A. A. S., Lucena, A. L. M. \& Lapenta, A. S. (2011). Identificação e caracterização das esterases em Tribolium castaneum (Coleoptera: Tenebrionidae). Revista Saúde e Biologia, v.6, n.1, p.2535.

15. Goergen, P. (2016). Extratos de schinus terebinthifolius no controle de sitophilus spp em grãos de trigo armazenado. Unijuí. TCC Agronomia. Disponível em: http://bibliodigital.unijui.edu.br:8080/xmlui/handle/123456789/3979.

16. Gómez, M. N. L. G. L. \& Machado, R. R. (2007). A ciência invisível: o papel dos relatórios e as questões de acesso à informação científica. Data Grama Zero, v. 8, n. 5, p. A05-0.

17. Grisi, P. U. \& Santos, C. M. (2007). Influência do armazenamento, na germinação das sementes de girassol. Horizonte Científico, v.1, n.7, $14 \mathrm{p}$.

18. Howe, R. W. (1956). Thexbiology of the two common storage species of Oryzaephilus (Coleoptera:Cucujidae). Ann. Appl. Biol. 44: 341342. 
19. Instituto Brasileiro do Meio Ambiente e dos Recursos Naturais Renováveis (2008). Instrução Normativa Conjunta $n^{o} 01$ de 15/04/2008.

20. Koehler, P. G. (1994). Rice Weevil, Sitophilus oryzae (Coleoptera: Curculionidae). Gainesville, FL. U. S. Department of Agriculture, UF/IFAS, Disponivel em: http://edis.ifas.ufl.edu/pdffiles/IG/IG12000.pdf.

21. Lima, B. M. F. V., Moreira, J. O. T. \& Aragão, C. A. (2013). Avaliação de extratos vegetais no controle de mosca-branca, Bemisia tabaci biótipo B em abóbora. Revista ciência agronômica, v. 44, n. 3, p. 622627.

22. Loeck, A. E. (2002). Praga de Produtos Armazenados. Pelotas: EGUFPEL, 113p.

23. Lorini, I. \& Schneider, S. (1994). Pragas de Grãos Armazenados: resultados de pesquisa. Passo Fundo: EMBRAPA-CNPT, 47p.

24. Lorini, I. (2008). Manejo Integrado de Pragas de Grãos de Cereais Armazenados. Passo Fundo: Embrapa Trigo, 72p.

25. Lorini, I., Krzyzanowski, F. C., França-Neto. J. B. \& Henning. A. A. (2010). Principais pragas e métodos de controle em sementes durante o armazenamento. Série sementes. Paraná: Embrapa, 12p.

26. Machado, L. A., Silva, V. B. \& Oliveira, M. M. (2007). Uso de extratos vegetais no controle de pragas em horticultura. Biológico, v.69, n.2, p.103-106.

27. Migliorini, P., Lutinski, J. \& Garcia, F. (2010). Eficiência de extratos vegetais no controle de Diabrotica speciosa (Coleoptera: Chrysomelidae), em laboratório. Florianópolis, Biotemas. v. 23, n. 1, p. 83-89.

28. Nakano, O., Neto, S. S., Carvalho, R. P. L., Baptista, G. C., Filho, E. B., Parra, J. R. P., Zucchi, R. A., Alves, S. B., Vedramim, J. D., Marchini, L. C., Lopes, J. R. S. \& Omoto, C. (2002). Entomologia Agrícola, São Paulo: Fealq, 920 p.

29. Oliveira, J. M. (2013). Potencial de extratos vegetais no controle de Polyphagotarsonemus latus, Tetranychus urticae e Myzus persicae. Viçosa, 72 f. Dissertação (Programa de Pós-Graduação em Entomologia). Universidade Federal de Viçosa.

30. Pimentel, M, Santos, J \& Lourini, I. (2001). EMBRAPA. Milho e sorgo. Disponível

em: http://www.cnpms.embrapa.br/publicacoes/milho_8_ed/prsementes.h $\underline{\mathrm{tm}}$.

31. Pontes, F S. S. (2005). Atividade inseticida de extratos e óleos vegetais sobre ninfas de pulgão preto do feijoeiro (Aphis craccivora koch). 47 
f. Monografia. (Curso de Agronomia do Centro de Ciências Agrárias). Universide Federal do Ceará.

32. Poy, L. A. (1991). Ciclo de vida de Rhyzopertha dominica (fabricius, 1972) col., Bostrychidae) em farinhas e grãos de diferentes cultivares de trigo. 135p. Dissertação. Universidade Federal do Paraná.

33. Revista Fi. (2010). Extratos Vegetais. Revista Food Ingredients Brasil. n.11. Disponível em: http://revista-fi.com.br/edicoes/11/fib-guia-defornecedores-2010.

34. Roscoe, R., Lourenção, A. L. F., Grigolli, J. F. J., Melotto, A. M., Pitol, C. \& Miranda, R. A. S. (2013). Tecnologia e Produção, Milho Safrinha e Culturas de Inverno, Maracaju: Fundação MS Para Pesquisa e Difusão de Tecnologias Agropecuárias. Disponível em: http://www.fundacaoms.org.br/tecnologia-e-producao-milhosafrinha-e-culturas-de-inverno-2013.

35. Santos, B. (2007). A origem e a importância dos insetos como praga das plantas cultivadas. Paraná: UFPR, 46p. disponível em: http://docplayer.com.br/12750389-A-origem-e-a-importancia-dosinsetos-como-pragas-em-plantas-cultivadas-prof-dr-braulio-santoseng-agr-entomologista-bsantos-ufpr.html.

36. Santos, J. P. Controle de pragas durante o armazenamento de milho. Sete Lagoas: EMBRAPACNPMS. 2006. 20p. (Circular técnica, 84)

37. Santos C. A. B. \& Silva A. P. M. (2015a). Viabilidade do uso de inseticidas botânicos extraídos de plantas exóticas. Educação Ambiental em Ação, XIV (54): 1-11.

38. Santos C. A. B. \& Silva A. P. M. (2015b). Extratos vegetais de plantas daninhas contra o pulgão Aphis craccivora Koch 1854, no feijão Vigna unguiculata (L.) Walp. Revista Ibero-Americana de Ciências Ambientais, v.6, n.2, p. 1-7.

39. Santos C. A. B., Silva A. P. M., Scher, F. A., Rocha, A. G., Silva, J. A. \& Moreira, J, O, T. (2011). Atividade inseticida de extratos vegetais contra o pulgão (Aphis craccivora Koch) do feijão caupi (Vigna unguiculata). Cadernos de Agroecologia v. 6, n. 2, p. 1-5.

40. Silva, M. L. L. S. (2013). Uso de extratos de plantas da caatinga no controle da cochonilha-do-carmim (Dactylopius opuntiae) em palma forrageira (Opuntia ficus-indica) 83 f. Dissertação (Programa de PósGraduação em Produção Vegetal). Universidade Federal Rural de Pernambuco, Serra Talhada.

41. Silva, R. A. \& Carvalho, S. G. (2000). Ocorrência de insetos na cultura do milho em sistema de plantio direto, coletados com armadilhas-de-solo. Ciência Rural, v. 30, n. 2, p. 199-203. 
42. Souza, R. \& Evangelista, W. (2009). Seleção e obtenção de extratos de plantas para utilização no controle de pragas na agricultura familiar. Revista Agroecossistemas, v. 1, n. 1, p. 27-27.

43. Souza, J. L. \& REZENDE, P. (2003). Manual de horticultura orgânica. Viçosa: Aprenda Fácil.

44. Thomazini, A. P. B. W., Vendramim, J. D. \& Lopes, M. T. R. (2000). Extratos aquosos de Trichilia pallida e a traça-do-tomateiro. Sciencia Agrícola, v. 57, p. 13-17. 